\title{
Influence on Foliar Nutrition on Yield Attributes and Yield of Rice Fallow Cow Pea
}

\author{
R. Jeyajothi ${ }^{1}$, V. Jothika ${ }^{2}$, M. Rakesh ${ }^{2}$, T. Aswathkumar ${ }^{2}$ and S. Mohan kumar ${ }^{2}$ \\ ${ }^{1}$ College of Agricultural Technology, Theni, India \\ ${ }^{2}$ Department of Agronomy, College of Agricultural Technology, Theni, India
}

*Corresponding author

\section{A B S T R A C T}

\begin{tabular}{|l|}
\hline K e y w o r d s \\
$\begin{array}{l}\text { Foliar nutrition, Cow } \\
\text { pea, Yield, Sea weed } \\
\text { liquid fertilizer, Pod } \\
\text { length and yield } \\
\text { attributes }\end{array}$ \\
\hline Article Info \\
\hline $\begin{array}{l}\text { Accepted: } \\
\text { 08 June } 2018 \\
\text { Available Online: } \\
\text { 10 July } 2018\end{array}$ \\
\hline
\end{tabular}

\section{Introduction}

Cow pea has multiple uses like food, feed, forage, fodder, green manuring and vegetable. An important component of farming system in resource constraints agriculture, this legume has great potential in India for successful cultivation in kharif and summer in northern India and throughout the year in peninsular India. Cowpea seed is a nutritious component in the human diet, and cheap livestock feed as well. The seed contains protein 22-24\%, Iron $0.005 \%$, Calcium $0.08-0.11 \%$ and Essential amino acids contains lysine, leucine and phenylalanine in higher amount. It also leave
$30-40 \mathrm{Kg} \mathrm{N} / \mathrm{ha}$ in the soil for the succeeding crop (Pulses in India Retrospect and Prospects-2016).

In India, cowpea is grown as sole, inter-crop, mix-crop and in agro-forestry combinations. In Indian context, it is a minor pulse cultivated mainly in arid and semi arid tracts of Rajasthan, Karnataka, Kerala, Tamilnadu, Maharashtra and Gujarat. In North India, it is grown in pockets of Punjab, Haryana, Delhi, and West UP along with considerable area in Rajasthan (Pulses in India Retrospect and Prospects-2016). India occupies an area of 3.9 million hectares with production of 2.2 million 
tonnes and productivity of $564 \mathrm{~kg} \mathrm{ha}^{-1}$ (Kurer et al., 2010). Rice fallows are widely distributed in rainfed eco-system of Eastern, Central and Peninsular India, besides North Eastern Hilly region. Coastal region like Andhra Pradesh, Odisha, Tamil Nadu accounts $1.52 \mathrm{~m}$ ha.

Short-duration varieties of pulses like lentil, mungbean, urdbean, lathyrus, field peas and oilseeds such as mustard, groundnut, linseed, niger, safflower and sesame etc, could be profitably cultivated in Rabi/Summer season in rice fallows. In addition, pulses and groundnut being leguminous crops will also help in restoration of soil health through nitrogen fixation.

Jothinayagi and Anbazhagan (2009),reported that lower concentration (20\%) of Seaweed Liquid Fertilizer (SLF) of Sargassum wightii extract promoted the shoot length, root length, fresh weight, dry weight, chlorophyll, carotenoid, protein, amino acid, reducing sugar, total sugar, $\alpha$ - amylase and $\beta$-amylase activities in Abelmoschus esculentus. Keeping this view, the present study was carried out to study the "Influence on foliar nutrition on yield attributes and yield of rice fallow Cow pea under rice fallow condition" during summer 2018.

\section{Materials and Methods}

A field experiment was conducted on "Influence on foliar nutrition on yield attributes and yield of rice fallow Cow pea under rice fallow condition during summer 2018 at College of Agricultural Technology, Kullapuram, Theni and belongs to the Southern agro climatic zone of Tamil Nadu. The experimental site is situated at $10^{\circ}{ }^{\circ}$ North latitude and $77^{\circ} 5$ ' East longitude at an altitude of $540 \mathrm{~m}$ from Mean Sea Level. Cowpea variety ( $\mathrm{CO} 7)$ was selected as a test crop. The experiment comprised of 9 treatment combinations with DAP (2\%), urea (2\%), TNAU Pulse Wonder (2 kg), Humic acid (2\%), Panchagavya (2\%), Seaweed Liquid Fertilizer (2\%), PPFM (1\%) and Polyfeed (1\%) which are laid out Randomized Block Design (RBD) with three replications. The treatment details are $\mathrm{T}_{1}-\mathrm{NPKS}+2 \%$ DAP; $\mathrm{T}_{2}-\mathrm{T}_{1}+2 \%$ urea; $\mathrm{T}_{3}-\mathrm{T}_{1}+$ TNAU Pulse Wonder $(2 \mathrm{~kg}) ; \mathrm{T}_{4}-\mathrm{T}_{1}+2 \%$ Humic acid; $\mathrm{T}_{5^{-}} \mathrm{T}_{1}+2 \%$ Panchagavya; $\mathrm{T}_{6^{-}} \mathrm{T}_{1}+$ Seaweed Liquid Fertilizer (2\%); $\mathrm{T}_{7}-\mathrm{T}_{1}+$ PPFM (1\%); $\mathrm{T}_{8^{-}} \mathrm{T}_{1}+$ Polyfeed (1\%); $\mathrm{T}_{9^{-}}$ NPKS alone. Soil available nutrients (NPK), soil $\mathrm{pH}$ and EC determined by standard procedures laid out by Jakson (1973) ${ }^{[3]}$. Fischer's method of analysis of variance was used for analysis and interpretation of the data as outlined by Panse and Sukhatme $(1985)^{[6]}$.

\section{Results and Discussion}

\section{Yield attributes}

Application of fertilizer to both preceding rice as well as basal application to cowpea significantly influenced the grain yield of rice fallow cowpea. Rice fallow cowpea applied with NPKS $+2 \%$ DAP along with Seaweed Liquid Fertilizer $\left(\mathrm{T}_{6}\right)$ recorded the highest number of seeds per pod, number of pods per plant, pod length and 100 seed weight value of $17.35,21.83,18.10 \mathrm{~cm}$ and $16.89 \mathrm{~g}$ which is followed by NPKS $+2 \%$ DAP along with $2 \%$ Humic acid (16.71, 20.68, $17.02 \mathrm{~cm}$ and 15.67 g) whereas NPKS alone founded the lowest value of $11.89,17.30,1210 \mathrm{~cm}$ and $13.03 \mathrm{~g}$ respectively (Table 1 and 2).

Adequate and continuous nutrient availability through soil and foliar nutrition promotes the supply of assimilates to sink or yield container, thus enlarging the size of the yield structure. The findings of Raghuwanshi et al., (1993), Hamayun and Chaudhary (2004) and Muhammad Hamayun et al., (2011) are in conformity the results of present study. 
Table.1 Effect of foliar nutrient on yield attributes of rice fallow cowpea

\begin{tabular}{lcccc}
\hline Treatments & No. of pods plant & No. of seeds pod & Pod length & 100 g wt \\
\hline $\mathrm{T}_{1}-\mathrm{NPKS}+2 \%$ DAP & 19.44 & 13.84 & 14.80 & 14.55 \\
$\mathrm{~T}_{2}-\mathrm{T}_{1}+2 \%$ Urea & 19.48 & 12.51 & 13.10 & 14.37 \\
$\mathrm{~T}_{3}-\mathrm{T}_{1}+\mathrm{TNAU}$ PW & 20.53 & 14.81 & 14.53 & 14.83 \\
$\mathrm{~T}_{4}-\mathrm{T}_{1}+2 \%$ Humic acid & 20.68 & 16.71 & 17.02 & 15.67 \\
$\mathrm{~T}_{5}-\mathrm{T}_{1}+2 \%$ Panchakavya & 20.22 & 15.85 & 16.10 & 14.16 \\
$\mathrm{~T}_{6}-\mathrm{T}_{1}+2 \%$ SLF & 21.83 & 17.35 & 18.10 & 16.89 \\
$\mathrm{~T}_{7}-\mathrm{T}_{1}+1 \%$ PPFM & 18.50 & 12.35 & 12.40 & 13.76 \\
$\mathrm{~T}_{8}-\mathrm{T}_{1}+1 \%$ PF & 18.43 & 12.85 & 13.53 & 13.93 \\
$\mathrm{~T}_{9}-\mathrm{NPKS}$ alone & 17.30 & 11.89 & 12.10 & 13.03 \\
\hline $\mathrm{SEd}$ & 1.77 & 2.27 & 1.98 & $\mathrm{NS}$ \\
$\mathrm{CD}$ & 3.75 & 4.83 & 4.20 & $\mathrm{NS}$ \\
\hline
\end{tabular}

Table.2 Effect of foliar nutrient on grain yield $\mathrm{kg} \mathrm{ha}^{-1}$, bhusa yield $\mathrm{kg} \mathrm{ha}^{-1}$, harvest index (\%) of rice fallow cowpea

\begin{tabular}{lccc}
\hline Treatments & Grain yield & Bhusa yield & Harvest index \\
\hline $\mathrm{T}_{1}-\mathrm{NPKS}+2 \%$ DAP & 1339 & 2951 & 31.08 \\
$\mathrm{~T}_{2}-\mathrm{T}_{1}+2 \%$ Urea & 1273 & 2945 & 30.25 \\
$\mathrm{~T}_{3}-\mathrm{T}_{1}+\mathrm{TNAU}$ PW & 1368 & 3255 & 30.49 \\
$\mathrm{~T}_{4}-\mathrm{T}_{1}+2 \%$ Humic acid & 1473 & 3682 & 30.89 \\
$\mathrm{~T}_{5}-\mathrm{T}_{1}+2 \%$ Panchakavya & 1452 & 3499 & 30.01 \\
$\mathrm{~T}_{6}-\mathrm{T}_{1}+2 \%$ SLF & 1600 & 4445 & 31.74 \\
$\mathrm{~T}_{7}-\mathrm{T}_{1}+1 \%$ PPFM & 1041 & 2185 & 29.57 \\
$\mathrm{~T}_{8}-\mathrm{T}_{1}+\mathrm{PF}$ & 1257 & 2765 & 29.32 \\
$\mathrm{~T}_{9}-\mathrm{NPKS}$ alone & 1031 & 1896 & 39.05 \\
$\mathrm{~S} \mathrm{Ed}$ & 290 & 434 & 3.14 \\
$\mathrm{CD}$ & 616 & 892 & $\mathrm{NS}$ \\
\hline
\end{tabular}




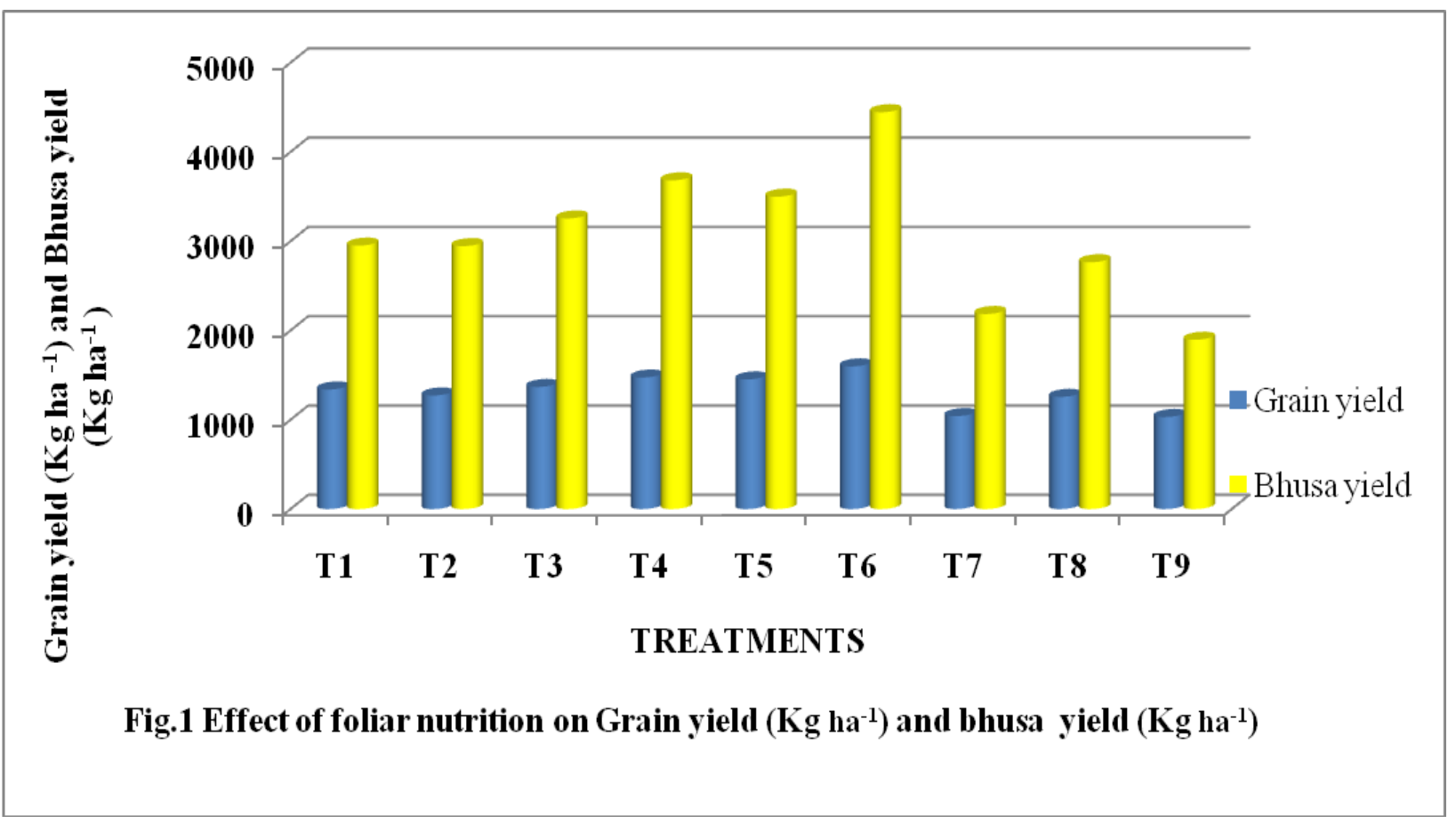

\section{Yield}

The residual effect of different nutrient management practices under both cultivation methods practiced for rice crop were influenced the yield of black gram significantly during experimentation. The higher seed yield and bhusa yield of $1598 \mathrm{~kg}$ $\mathrm{ha}^{-1}$ and $4445 \mathrm{~kg} \mathrm{ha}^{-1}$ respectively were obtained in the treatment with NPKS $+2 \%$ DAP along with Seaweed Liquid Fertilizer $\left(\mathrm{T}_{6}\right)$ which is followed by $1473 \mathrm{~kg} \mathrm{ha}^{-1}$ and $3682 \mathrm{~kg} \mathrm{ha}^{-1}$ respectively on foliar application of NPKS $+2 \%$ DAP along with $2 \%$ Humic acid whereas NPKS alone recorded the lowest seed yield and bhusa yield of $1031 \mathrm{~kg} \mathrm{ha}^{-1}$ and $1896 \mathrm{~kg} \mathrm{ha}^{-1}$ respectively.

The impact of the foliar nutrients (macro and micro) to meet the nutrient demand of the crop at the critical stage on-site availability, where they are needed without stress, would have resulted in better growth and development of the crop and ultimately the yield attributing characters and yield. The balanced growth habit, which induced more flower and fruiting body production with timely supply of nutrients through foliar spray, might have reduced shedding of flowers and fruits, which led to a positive source-sink gradient of photosynthates translocation due to growth regulator on the other hand. These favourable effects might have attributed to higher yield of cowpea under the foliar spray of nutrients and growth regulators. This finding is in line with the results of Manivannan et al., (2003) ${ }^{[4]}$ who had recorded higher grain yield of cowpea by foliar application of microsol (NPK with micronutrients).

It is concluded that the result showed that foliar application along with recommended NPKS $+2 \%$ DAP $+2 \%$ Seaweed Liquid Fertilizer significantly enhanced the yield attributes like seeds per pod, number of pods per plant, pod length and 100 seed weight, seed yield and bhusa yield of higher in the treatment. It could be concluded that among the various foliar nutrition, combination of NPKS $+2 \%$ DAP $+2 \%$ Seaweed Liquid Fertilizer for suitable for farmers for achieving higher yield in cow pea production under rice fallow condition. 


\section{References}

Bastia DK, Garnayak LM and Barik T. Diversification of rice (Oryza sativa) based cropping systems for higher productivity, resource-use efficiency and economics. Indain J. Agronomy. 2008;53(1): 22-26.

Hamayun M and Chaudhary MF. Effect of foliar and soil application of NPK on different growth parameters and nodulation in lentil. Sarhad J. Agric. 2004;20: 103-111.

Jackson ML, Soil Chemical Analysis. Prentice Hall Pvt. Ltd., New Delhi, 1973.

Manivannan V and Thanunathan K. Effect of foliar nutrition of major and chelated micronutrients and Rhizobium seed treatment on rice-fallow blackgram. Madras Agric. J. 2003; 90(4-6): 344347.

Muhammad Hamayun, Sumera AK, Abdul LK, Zabta KS, Nadeem Ahmad,
Yoon-Ha Kim and In-Jung Lee. Effect of foliar and soil application of nitrogen, phosphorus and potassium on yield components of lentil. Pak. J. Bot. 2011; 43(1): 391-396.

Panse VG and Sukhatme PV. Statistical methods for agricultural workers Indian Council of Agricultural Research (IARI), New Delhi, 1985, 167-174.

Prasad D, Yadava MS and Singh CS. Diversification of rice (Oryza sativa) based cropping systems for higher productivity, profitability and resource-use efficiency under irrigated ecosystem of Jharkhand. Indain J. Agronomy. 2013; 58(3): 264-270.

Raghuwanshi MS, Rathi GS and Sharma RS. Effect of foliar spray of diammonium phosphate and urea on the growth and yield of chickpea. JNKVV. Res. J. 1993; 27 (1): 131-132.

\section{How to cite this article:}

Jeyajothi, R., V. Jothika, M. Rakesh, T. Aswathkumar and Mohan Kumar, S. 2018. Influence on Foliar Nutrition on Yield Attributes and Yield of Rice Fallow Cow Pea. Int.J.Curr.Microbiol.App.Sci. 7(07): 1187-1191. doi: https://doi.org/10.20546/ijcmas.2018.707.143 